\title{
Effect of Organizational Justice on Organizational Citizenship Behaviour at Barombong Maritime Polytechnic Makassar City
}

\author{
Ilham Ashari ${ }^{1}$, Rahmat ${ }^{2}$, Atta Irene Allorante ${ }^{3}$, Badu Ahmad ${ }^{3}$ \\ 1) Doctoral Student in Public Administration Hasanuddin University of Makassar \\ ${ }^{2)}$ Professor in Hasanuddin University of Makassar \\ ${ }^{3)}$ Associate Professor in Hasanuddin University of Makassar
}

\begin{abstract}
Organizational justice emerged as an essential concept in predicting Organizational Citizenship Behavior (OCB). However, in various studies, there are still gaps in research results where organizational justice will not always affect $\mathrm{OCB}$. Thus, the researcher aims to analyze the effect of Emotional Intelligence on the OCB employee at Barombong Maritime Polytechnic Makassar City. The design of this study is quantitative research with a cross-sectional approach. The sample in this study were all civil servants as many as 75 people. The statistical test used is the SEM analysis test with AMOS software. The findings of this study are organizational justice has a positive and significant effect on the OCB employee at Polytechnic of Shipping Makassar City, which is statistically proven where the significance value is less than 0.05 or $(0,000<0.05)$ and the $C R$ value is positive and is greater than $1.96(3.441>1.96)$. This research implies that when organizational justice is improved, OCB will also increase.
\end{abstract}

Keywords:- Organizational Justice, Organizational Citizenship Behaviour.

\section{INTRODUCTION}

Human Resource Management (HRM) is needed in managing organizations, public organizations and private organizations. HRM means managing people within the organization to be willing and able to achieve some of the goals that have been planned and agreed upon by all citizens in an organization. Humans who have a mind make it different from one human to another. The difference will become a conflict if managers in the organization can not adequately manage it.

In this case, Organizational Citizenship Behavior (OCB) increases the tendency to help and share information, possess a sense of responsibility, respect commands and rules, have motivation, increase job satisfaction and have commitment to the organization which will significantly influence organizational performance (Triyanto, 2009; Chahal and Mehta, 2010; Mallick et al., 2015). For this reason, OCB is indispensable for employees to establish communication and collaboration among health staff, managers, and patients to improve the quality of work of public service agencies (Altuntas and Baykal, 2014).
Much research has been done on OCB because the role of OCB is individual behaviour that is considered vital and dramatically influences the effectiveness of the organization (Darto, 2014). From the literature review, antecedent factors that influence OCB include justice / organizational justice \& motivation perceptions (Smith, Organ and Near, 1983; Moorman, 1991; Podsakoff et al., 2000; Chahal and Mehta, 2010; Jafari and Bidarian, 2012 ). In this research, will examine organizational justice as an essential factor in influencing employee OCB. Organizational Justice is an individual's subjective perception of how they are treated fairly in the organization, and that perception does affect employee loyalty to the organization (Nandan, Mutalib and Azim, 2015; Mahendra and Surya, 2017).

Organizational justice emerged as an essential concept in predicting $\mathrm{OCB}$, and several studies found a positive relationship between these two variables (Mahmoud and Ibrahim, 2016). Research by Ismail et al. (2018) on 700 employees at Azad Jammu and Kashmir universities found a significant relationship between organizational Justice, OCB and Employee Performance. Organizational Justice and OCB are positively related to each other with employee performance, attitudes and work behaviour of employees depending on the perception of fair justice from the organizational results they receive from their organizations (Ismail, Iqbal and Adeel, 2018).

Conversely, if employees feel mistreated, it can foster negative feelings and lead to deviant behaviour (Aquino, Lewis and Bradfield, 1999). So that it will reduce employee performance and have an impact on weakening morale, increased stress levels, intragroup conflicts, poor teamwork, (Pekurinen et al., 2017), increased absenteeism and turnover (Fardid, Nahid Hatam and Zahra Kavosi, 2018), decreased commitment to the organization thereby reducing OCB behavior, and performance (Colquitt, 2001, 2012; Skinner et al., 2018; Cropanzano and Rupp, 2003; Ardi and Sudarma, 2015).

On the other hand, organizational justice is, in principle, an individual's subjective perception of how they are treated fairly in the organization, and that perception will shape employee loyalty to the organization. (Nandan, Mutalib and Azim, 2015; Mahendra and Surya, 2017), meaning that organizational justice will only have an impact on employee loyalty, but will not necessarily provide a change in better work behaviour. This was also stated in the 
concept of OCB by Bamard (1938) that OCB was formed from a willingness to cooperate, even Katz (1964) used a similar concept and was introduced as innovative and spontaneous behaviours (Podsakoff et al., 2000 ).

The Shipping Polytechnic Organization has 274 employees consisting of 75 civil servants and non-ASN civil servants 199. The organization is a provider of educational services in the shipping sector. Besides that, the Shipping Polytechnic is expected to be able to achieve the targets in the delivery of cruise education services which required good OCB from employees. From this study, this research will focus on analyzing the analysis of the influence of organizational justice on the OCB employee at Barombong Maritime Polytechnic Makassar City.

\section{LITERATURE REVIEW}

\section{A. Organizational Citizenship Behavior}

According to Organ (1988), Organizational Citizenship Behavior (OCB) is voluntary work behavior, is not associated with a formal reward or reward system and is a single entity that can contribute to increasing organizational effectiveness. Voluntary, because the behavior refers to behavior that is not part of the employee's job description formally but as a personal choice (Podsakoff et al., 2000).

Organ (1988) uses five dimensions as a factor that determines OCB employees in an organization or work environment. These five factors include altruism, conscientiousness, courtesy, civic virtue, and sportmanship. Furthermore, William and Anderson (1991) then divided the five dimensions into two categories namely OCBOrganization (OCB-O) consisting of civic virtue and sportsmanship dimensions and OCB-Individual (OCB-I) consisting of dimensions of altruism, conscientiousness, and courtesy.

OCB-O is beneficial behavior towards organizations such as obeying existing informal rules to maintain order. Whereas OCB-I are behaviors that directly benefit other individuals and indirectly also contribute to the organization, such as helping to complete the work of colleagues who were not present that day (L. J. Williams and Anderson, 1991).

Even so, the five things remain a unified OCB dimension which is explained in more detail as follows (Chahal and Mehta, 2010):

1. Altruism, is the behavior of helping others or coworkers without being asked first. That is, this behavior has the initiative of employees to help. In the Public Service Agency, actions that can be taken are to help other employees such as medical or non-medical personnel according to their competency. This is done to achieve organizational goals.

2. Conscientiousness, is a disciplined attitude at work for example by following organizational rules even when no one is watching, and making the most of the best possible time. In the Public Service Agency, employees should avoid talking as much as possible which only wastes time which disrupts service time. In addition, doctors are also expected to conduct visits according to a predetermined schedule and provide excellent service.

3. Courtesy, is the behavior of trying to prevent a problem from occurring For example, employees of the Public Service Agency in this case medical staff will try to do the best for their patients. Through this behavior, employees help to prevent a problem from happening, or act ahead to reduce the risk that will occur (Organ, 1988). If altruism focuses on helping to solve something or a problem that has happened, courtesy helps to prevent that from happening.

4. Civic virtue, is a behavior where active employees in the organization include support for administrative and organizational functions, participate, be responsible and with full awareness show concern for the survival of the organization.

5. Sportsmanship, is a behavior that always tolerates discomfort that occurs in the workplace and tries to understand things that are disruptive. For example in the Public Service Agency, for example, by embracing the culture of no blame culture, rather than blaming or looking for those who make mistakes, the organization is better to do an evaluation and introspection so that similar mistakes do not happen again. Sportsmanship shows tolerance for the shortcomings of ideal conditions at work without complaining (Podsakoff, MacKenzie, Moorman, \& Fetter, 1990).

\section{B. Organizational Justice}

Organizational justice is an individual's subjective perception of how they are treated fairly in the organization, and that perception does affect employee loyalty to the organization. (Nandan, Mutalib and Azim, 2015; Mahendra and Surya, 2017). The theory of justice was first popularized by J. Adams in 1963. This theory assumes that individuals compare the ratio between income or rewards and the contribution of the work they do then compared to others. Injustice arises when the ratio is not the same (Greenberg, 1990).

Justice is often the center of attention of organizations and human rights, because everyone in any situation and context wants fair treatment by other parties, as well as in organizations. Employees' perceptions of organizational justice are important predictors of employee positive work attitudes. Employees who feel treated fairly by the organization will hold commitment, have confidence in management and leadership, satisfaction, sense of belonging to each other and increase OCB employees so that they contribute to retaining employees in the organization (Cohen-Charash \& Spector, 2001; Colquitt, Conlon, Wesson, Porter, \& Ng, 2001; Cropanzano, Bowen, \& Gilliland, 2007; Greenberg, 1990).

Organizational justice according to Niehoff and Moorman (1991) is an allocation of justice that is measured through three dimensions, namely distributive justice, procedural justice and interactive justice. Then, Colquitt (2001) developed that organizational justice is not only three dimensions, but can be measured from four dimensions namely procedural justice, distributive justice, interpersonal 
justice, and informational justice. The interactive justice dimension of organizational justice developed by Niehoff and Moorman (1991), in Colquitt's (2001) view, developed it into interpersonal justice and informational justice, and this is in line with the dimension proposed by Greenberg that organizational justice is better when measured using four dimensions compared to using two or three dimensions (Colquitt, 2001).

\section{Procedural Justice}

Procedural justice related to organizational decision processes is made and said to be fair if employees feel given the opportunity to be involved in the decision making process (Robbins, 2013). Procedural justice is justice that arises because the company has provisions and procedures that in its implementation reflect justice, namely justice in decision making (Folger and Konovsky in Srikant and Gurunathan, 2013). Procedural justice refers to the fairness that is felt in employee decision-making procedures. Procedures are evaluated by their level of consistency, biased emphasis, accuracy, corrections, ethicality and the extent to which customers allow voice and input (Leventhal, Thibaut and Walker in Colquitt and Rodell, 2011).

\section{Distributive Justice}

Greenberg (1990) explains that Adams's theory of justice is complemented by further research related to the allocation of rewards known as distributive justice. Robbins and Judge (2008) define distributive justice as the fairness of the amount and respect felt among individuals. Distributive justice relates to the reasonableness of resource allocation and rewards to employees in the form of salary or incentives. Distributive justice is justice that is most often judged on the basis of fairness of results, which states that employees should receive wages / salaries in accordance with their income and expenditure relative to the referent / other ratio (Adams, 1965; cohen, 1987) (Cohen-Charash and Spector, 2001). Distributive justice occurs when employees feel that contributions to work and rewards are appropriate and comparable to other employees (Jafari and Bidarian, 2012). The purpose of distributive justice is welfare which covers physical, psychological, economic, and social aspects, so that what is distributed is usually related to resources, rewards or benefits (Khasanah, 2015).

\section{Interpersonal Justice}

Bies and Moag (1986) state that interpersonal justice is a person's sensitivity to the quality of interpersonal treatment received during the course of organizational procedures. Greenberg (1993) also suggests that interpersonal justice is a social aspect of procedural justice. Interpersonal justice is defined as the degree to which a person is treated with courtesy, respect and dignity (Meru \& Fajrianthi, 2013). In the context of interpersonal justice organizations related to the perception of the communication process between superiors and subordinates.

\section{Informational Justice}

Greenberg (1993) states that informational justice is a determinant / social factor of procedural justice. Informational justice can arise by providing information about the processes and procedures for making decisions. The information is given in order to show that the organization / supervisor is paying attention to the concerns of subordinates. For example, when someone receives a negative result such as a proposal being rejected or the job is rejected, it is more likely to accept the result as fairness when they receive a reasonable explanation of the procedure used when making decisions. Bies and Shapiro (1987) describe information justice as a perception of whether the party determining the decision has provided an explanation of the outcomes affecting the individual.

\section{RESEARCH METHOD}

The design of this study is a quantitative study using an analytic observational design and cross-sectional approach. This research was conducted at Barombong Maritime Polytechnic Makassar City with a sample of 75 civil servant employees.

The instrument used in this study was a questionnaire that would measure perceptions about organizational justice variables and organizational citizenship behaviour (OCB) variables. For organizational justice, variables are measured using four dimensions proposed by Colquitt (2001), namely procedural justice, distributive justice, interpersonal justice, and information justice. Meanwhile, Organizational Citizenship Behavior (OCB) variables are measured using five dimensions proposed by Organ (1988) and Chahal and Mehta (2010) namely altruism, conscientiousness, sportsmanship, civic virtue, and courtesy.

Hypothesis testing, it is necessary to have an appropriate analytical technique which in this study uses the Structural Equation Model (SEM) with the AMOS (Analysis Of Moment Structural) program. Factor Analysis (CFA) with AMOS software before testing the hypothesis. In this test, the indicator is declared valid if it has a loading factor value> 0.4 (Ferdinand, 2014), while the construct reliability test is performed by calculating construct reliability (CR), where the construct is declared reliable if the CR model > 0.7 (Hair et al. ., 2014). The next step is the regression weight/loading factor test to determine the significance of this study.

\section{RESULT}

\section{Measurement Model Testing}

The stages of testing the measurement model for the instrument used are testing the validity and reliability with Confirmatory Factor Analysis (CFA) with AMOS software before testing the hypothesis. Based on the results of testing the model of organizational justice construct measurement one of the indicators dropped from the model is the Procedure Justice (OJ1) indicator, while the other indicators have a loading factor value $>0.4$, so that all indicators are declared Valid. Then, the AVE value of the construct of 
ISSN No:-2456-2165

Organizational Justice has exceeded 0.5 , and the value of Construct Reliability (CR) has exceeded 0.7 so that all indicators in the construct of Organizational Justice have been reliable. Then, in testing the OCB construct measurement model, all indicators have a loading factor value> 0.4; AVE> 0.5; and Construct Reliability> 0.7, so that all indicators are declared Valid and reliable.

\section{Significance Test}

Structural model compatibility test in SEM analysis by looking at Goodness of Fit criteria models such as ChiSquare value, probability, CMIN / df, RMR, NFI, CFI, TLI, IFI, RFI, GFI, AGFI, and RMSEA. The fulfilment of the model goodness of fit will focus of Goodness of fit models indicator being met. Based on the results of testing the full model goodness of fit, the model shows that the model has been used to test the research hypothesis because there are no indicators that meet the fit requirements of a model by referring to the AMOS output on the modification indices table. The results of the model goodness of fit test after the model modification process is performed are shown in the Goodness of fit model criteria, namely:

\begin{tabular}{|c|c|c|c|}
\hline Criteria & $\begin{array}{c}\text { Cut-off } \\
\text { point }\end{array}$ & Result & Conclusion \\
\hline Chi-square & $\begin{array}{c}\text { Expected to } \\
\text { be small }\end{array}$ & 22,623 & Good \\
\hline $\begin{array}{c}\text { Significance } \\
\text { Probability }\end{array}$ & $\geq 0,05$ & 0,162 & Good \\
\hline CMIN/DF & $\leq 2,00$ & 1,331 & Good \\
\hline AGFI & $\geq 0,90$ & 0,857 & Marginal \\
\hline GFI & $\geq 0,90$ & 0,933 & Good \\
\hline TLI & $\geq 0,95$ & 0,949 & Good \\
\hline CFI & $\geq 0,95$ & 0,969 & Good \\
\hline RMSEA & $\leq 0,08$ & 0,067 & Marginal \\
\hline
\end{tabular}

Table 1:- Final Model Goodness of Fit Full Testing Results

With a significant level of 0.05 then Ho will be rejected if the significant value $(\mathrm{P})<0.05$ and c.r $>1.96$, while if the significant value $(\mathrm{P})>0.05$ and c.r $<1.96$ then Ho is not rejected.

\begin{tabular}{|l|l|c|c|c|c|c|c|}
\hline & & & Estimate & S.E. & C.R. & P & Label \\
\hline OCB & $<--$ & Organizational_Justice &, 595 &, 198 & 3,010 &, 003 & par_7 \\
\hline
\end{tabular}

Table 2:- Significance Test Results Regression Weights: (Group number 1 - Default model)

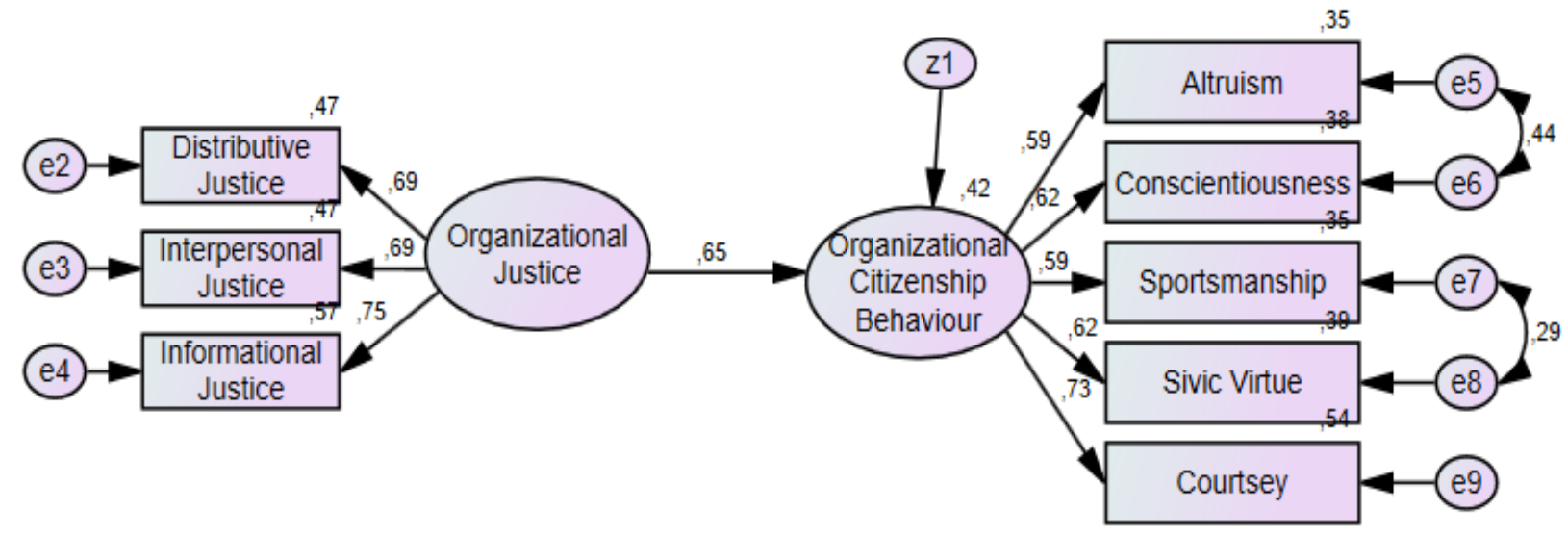

\section{GOODNESS OF FIT MODEL Chisquare=22,623; Prob=,162; CMIN/DF=1,331; DF=17 GFI=,933; AGFI=,857; TLI=,949; CFI=,969; RMSEA=,067}

Fig 1:- Structural Model Test Results

Based on the results of SEM analysis on the effect of Organizational Justice on Organizational Citizenship Behavior (OJ $\rightarrow$ OCB), a significance value or $p$-value of (0.003) was obtained, with a C.R value of 3.010 being positive. Because the significance is less than 0.05 or $(0.003$ $<0.05)$ and the value of C.R is positive and more significant than 1.96 (3.010> 1.96), organizational justice has a positive and significant effect on organizational citizenship behaviour (OCB). Thus, the hypothesis can be accepted. That is, the better organizational justice, the organizational citizenship behaviour (OCB) will also be better, and vice versa.

The results of this study are in line with research conducted by Ismail Research et al. (2018) of 700 employees at Azad Jammu and Kashmir universities who 
found a significant relationship between organizational justice, OCB and Employee Performance. Organizational justice and OCB are positively related to each other with employee performance, attitudes and work behaviour of employees depending on the perception of fair justice from the organizational results they receive from their organizations (Ismail, Iqbal and Adeel, 2018).

Organization Citizenship Behavior increases the tendency to help and share information, possess a sense of responsibility, respect commands and rules, have motivation, increase job satisfaction and have commitment to the organization which will significantly influence organizational performance (Triyanto, 2009; Chahal and Mehta, 2010 ; Mallick et al., 2015). For this reason, OCB is indispensable for employees to establish communication and collaboration among health staff, managers, and patients to improve the quality of work of Public Service Agency services (Altuntas and Baykal, 2014).

However, this finding differs from other researchers' findings that organizational justice is in principle an individual's subjective perception of how they are treated fairly in the organization, and that perception will shape employee loyalty to the organization. (Nandan, Mutalib and Azim, 2015; Mahendra and Surya, 2017), which means that organizational justice will only have an impact on employee loyalty, but will not necessarily provide a change in better work behavior. This was also stated in the OCB concept by Bamard (1938) that OCB was formed from the willingness to cooperate, even Katz (1964) used a similar concept and was introduced as innovative and spontaneous behavior (Podsakoff et al., 2000).

\section{CONCLUSIONS}

Organizational justice is the overall perception of what is fair at work. Employees consider their organization fair when they believe that the results they receive and the way they are received are fair. (Robbins and Judge, 2013). Therefore, organizational justice has a positive and significant effect on Organizational Citizenship Behavior for Barombong Maritime Polytechnic Makassar City. This means that organizational justice gives a significant influence so that when organizational justice is improved, the Organizational Citizenship Behavior also increases.

From these findings that Barombong Maritime Polytechnic Makassar City needs to pay attention to aspects of organizational justice especially in terms of distributive justice. For example, employees are rewarded for services that are in accordance with the work they have done. In addition, employees who are able to show performance need to be given a fairer and fairer award in the allocation of awards to each employee.

\section{REFERENCES}

[1]. Altuntas, S. and Baykal, U. (2014) 'Organizational citizenship behavior levels of nurses and effective factors', Sağlik ve Hemşirelik Yönetimi Dergisi, 1(2), pp. 89-98. doi: 10.5222/SHYD.2014.089.

[2]. Aquino, K., Lewis, M. U. and Bradfield, M. (1999) 'Justice constructs, negative a $€$ ectivity, and employee deviance: a proposed model and empirical test Dimensions of Deviant Behavior', Journal of Organizational Behavior, 20(January 1998), pp. 10731091. doi: 10.1002/(SICI)1099-1379(199912)20.

[3]. Chahal, H. and Mehta, S. (2010) 'Antecedents and Consequences of Organisational Citizenship Behaviour (OCB): A Conceptual Framework in Reference to Health Care Sector', Journal of Services Research, 10(2), pp. 25-44.

[4]. Colquitt, J. A. (2001). On the dimensionality of organizational justice: A construct validation of a measure. Journal of applied psychology, 86(3), 386.

[5]. Colquitt, J. A. (2012) 'Organizational Justice', 1(1975), pp. 526-547.

[6]. Cropanzano, R. and Molina, A. (2015) 'Organizational Justice', International Encyclopedia of the Social \& Behavioral Sciences: Second Edition, (December 2015), pp. 379-384. doi: 10.1016/B978-0-08-0970868.22033-3.

[7]. Darto, M. (2014) 'Peran Organizational Citizenship Behavior (OCB) Dalam Peningkatan Kinerja Individu Di Sektor Publik: Sebuah Analisis Teoritis Dan Empiris', Jurnal Borneo Administrator, 10(1), pp. 10 30.

[8]. F. Hair Jr, J., Sarstedt, M., Hopkins, L., \& G. Kuppelwieser, V. (2014). Partial least squares structural equation modeling (PLS-SEM) An emerging tool in business research. European Business Review, 26(2), 106-121.

[9]. Fardid, M., nahid hatam and zahra kavosi (2018) 'A Path Analysis of the Effects of Nurses' Perceived Organizational Justice, Organizational Commitment, and Job Satisfaction on their Turnover Intention', Nursing and Midwifery Studies, 7, pp. 33-38. doi: 10.4103/nms.nms.

[10]. Ferdinand, A. (2014). Metode Penelitian Manajemen. Semarang: Universitas. Diponegoro.

[11]. Ismail, S., Iqbal, Z. and Adeel, M. (2018) 'Impact of Organizational Justice and Organizational Citizenship Behavior on Employees Performance', 8(2), pp. 187200. doi: 10.5296/ijhrs.v8i2.13070.

[12]. Jafari, P. and Bidarian, S. (2012) 'The relationship between organizational justice and organizational citizenship behavior', 47, pp. 1815-1820. doi: 10.1016/j.sbspro.2012.06.905.

[13]. Mahendra, i made dika and Surya, ida bagus ketut (2017) 'Pengaruh Iklim Organisasi, Motivasi Kerja Dan Keadilan Organisasi Terhadap Organizational Citizenship Behavior (OCB)', 6(9), pp. 4659-4688.

[14]. Mahmoud, A., and S. Ibrahim. (2016). "Factors in nurses' organizational citizenship behavior." IOSR J Nurs Health Sci 5, no. 2 (2016): 22-28. 
[15]. Mallick, E., Pradhan, R. K., Tewari, H. R. and Jena, L. K. (2015) 'Organizational Citizenship Behaviour, Job Performance and HR Practices: A Relational Perspective', Management and Labour Studies, 39(4), pp. 1-12. doi: 10.1177/0258042X15578023.

[16]. Moorman, R. H. (1991) 'Relationship Between Organizational Justice and Organizational Citizenship Behaviors: Do Fairness Perceptions Influence Employee Citizenship ?', 76(6), pp. 845-855.

[17]. Nandan, T., Mutalib, A. and Azim, M. (2015) 'Organizational Justice and Organizational Citizenship Behavior: Mediating Role of Psychological Capital', 4(6), pp. 148-156.

[18]. Organ, D. W. (1988). Organizational Citiizenship Behavior: The Good Soldier Syndrome. Lexington: MA: Lexington Books

[19]. Podsakoff, P. M., Mackenzie, S. B., Paine, J. B. and Bachrach, D. G. (2000a) 'Organizational Citizenship Behaviors : A'. doi: 10.1177/014920630002600307.

[20]. Podsakoff, P. M., Mackenzie, S. B., Paine, J. B. and Bachrach, D. G. (2000b) 'Organizational citizenship behaviors: A critical review of the theoretical and future research', Journal of Management, 26(3), pp. 513-563. doi: 10.1177/014920630002600307.

[21]. Robbins, Stephen P., and Timothy A. Judge. Organizational behavior. Pearson education limited, 2013.

[22]. Skinner, N., Van Dijk, P., Stothard, C. and Fein, E. C. (2018) "'It breaks your soul": An in-depth exploration of workplace injustice in nursing', Journal of Nursing Management, 26(2), pp. 200-208. doi: 10.1111/jonm. 12535 .

[23]. Smith, C. A., Organ, D. W. and Near, J. P. (1983) 'Organizational Citizenship Behavior: Its Nature and Antecedents', 68(4), pp. 653-663.

[24]. Turnipseed, D. L. and Vandewaa, E. A. (2012) 'Relationship between Emotional Intelligence and Organizational Citizenship Behavior', Psychological Reports, 110(3), pp. 899-914. doi: 10.2466/01.09.20.21.PR0.110.3.899-914.

[25]. Triyanto, A. (2009). Organizational citizenship behavior (OCB) dan pengaruhnya terhadap keinginan keluar dan kepuasan kerja karyawan. Jurnal Manajemen Maranatha, 8(2), 52-65. 